\title{
Pola Tata Letak Situs Tradisi Megalitik Di DAS Sekampung
}

\section{R.r. Triwurjani}

Keywords: mound, distribution, pattern, river, spatial, area, settlement

\section{How to Cite:}

Triwurjani, R. (2000). Pola Tata Letak Situs Tradisi Megalitik Di DAS Sekampung. Berkala Arkeologi, 20(1), 87-109. https://doi.org/10.30883/jba.v20i1.810

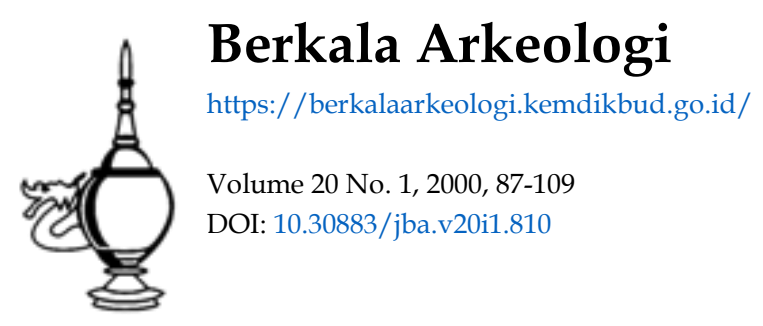

\section{(c) (1) (2)(2)}

This work is licensed under a Creative Commons Attribution-NonCommercial-ShareAlike 4.0 International License. 


\title{
POLA TATA LETAK \\ SITUS TRADISI MEGALITIK DI DAS SEKAMPUNG*
}

\author{
Rr.Triwurjani \\ (Pusat Arkeologi)
}

\section{Pendahuluan}

Pola sebaran situs diduga merupakan wujud konkret dari pola gagasan dan pola perilaku masyarakat masa lalu mengenai penempatan, dan penyebaran situs-situs daerah penelitian. Pemolaan keruangan situs-situs arkeologi mencerminkan pemolaan aktifitas manusia masa lalu yang didasarkan atas satu atau sekumpulan pertimbangan teknologis, ekologis, perilaku sosiologis ekonomis (Schiffer, 1972; Mundardjito, 1995).

Setiap tinggalan arkeologis ataupun situs menempati suatu ruang dalam bentang alam ini. Setiap komponen ruang ataupun situs dapat dikatakan sebagai wadah atau seting kegiatan tertentu dari perilaku manusia (Haryadi,1995).Hubungan antara komponenkomponen ruang atau seting kegiatan manusia disebut sistem seting. Konsep sistem seting adalah alat untuk menemukenali ruang-ruang yang merupakan wadah kegiatan manusia Dalam kondisi dimana manusia sebagai pelaku kegiatan sudah tidak ada lagi, maka tanda-tanda yang berupa spasial maupun fisik akan dapat mengganti ketidakhadiran manusia Tanda-tanda tersebut akan dapat memberikan gambaran tentang ruang baik kegiatan sehari-hari, mingguan, bulanan, tahunan ataupun kegiatan yang bersifat sesaat yang tidak ajeg (Haryadi, 1995).

Penentuan lokasi suatu situs tidak begitu saja dipilih melainkan berbagai pertimbangan, antara lain berhubungan dengan efektifitas energi, waktu yang dibutuhkan dalam mengeksploitasi dan mendistribusikan hasil-hasil subsistensi. Dengan demikian situs sebagai tempat manusia beraktifitas, dapat memberikan gambaran dan informasi tentang lokasi tempat keberadaanya, lingkungan alam dan teknologi yang dimiliki manusia pendukungnya.

Dengan demikian sebenarya situs-situs tersebut tidak acak melainkan mempunyai pola sebagai hasil pola pikir manusia pada kurun waktu tertentu. Pada normatif mengatakan bahwa pada dasarnya masyarakat tidak berperilaku acak melainkan mengikuti aturan (normatif) yang berlaku dalam masyarakat (Watson, 1971) Pandangan lain juga mengakui bahwa distribusi situs-situs arkeologi merefleksikan aktifitas-aktifitas

\footnotetext{
- Pernah disajikan dalam Evaluasi Hasil Penelitian Arkeologi, 16 -- 20 Februari 1998 di Cipayung. Jawa Barat.
} 
manusia yang berhubungan dengan pemanfaatan sumber yang berbeda (Butzer, 1964; Trigger, 965; Parson, 1972).

Dalam hal distribusi situs-situs arkeologi, dalam skala ruang dan waktu, maka situs yang hendak kita teliti lebih dari satu agar bisa dilihat perbedaan dan persamaan dalam hubungan antar situs maupuan antar benda-benda dalam situs itu sendiri manifestasi interaksi manusia dan lingkungan ini bisa disebut juga dengan landeskap (Crumley, William H., 1990).

Bidang kegiatan arkeologi ruang tidak hanya mengkaji hubungan lokasional atau keruangan antar artefak tetapi juga dengan dan terutama bentuk-bentuk data arkeologi yang disebut oleh Clarke sebagi unsur atau elemen-elemen yang terdiri dari struktur(fitur)situs dan lingkungan fisik yang dimanfaatkan sebagai sumberdaya lingkungan (Clarke, 1977; Mudarjito, 1995).

Untuk memudahkan mengambil bentuk-bentuk persamaan dan perbedaan maka studi kawasan ini akan lebih baik dibatasi dalam skala tertentu. Batasannya bisa bermacammacam, bisa dalam kawasan budaya tertentu, lingkungan tertentu, ataupun batas lain yang kita tentukan berdasarkan pertimbangan-pertimbangan yang dibahas dalam studi kawasan.

Ada 4 (empat) sasaran pokok kajian arkeologi ruang: mengkaji keruangan dari situssitus arkeologi; mengkaji sebaran dari sejumlah besar benda dan situs-situs arkeologi; mengkaji hubungan antara situs-situs arkeologi dan hubungan antara situs-situs itu dengan sumber daya alam dan sekitarnya; dan mengkaji semua itu dalam satuan daerah penelitian yang luas (kawasan) (Mundarjito, 1993).

Di daerah Lampung, khususnya di sepanjang DAS Sekampung banyak ditemui situssitus berupa gundukan tanah dan parit, ataupun parit saja. Pada sisi sebelah dalam dan luar dari gundukan tanah dan parit tersebut banyak mengandung peninggalan arkeologis, seperti punden, menhir, gumuk, dolmen, batu lumpang, batu berlubang, tembikar, porselen dan lain-lain.

Adapun batas wilayah yang menjadi ruang lingkup kajian ini adalah satuan unit DAS yang meliputi sungai utama Sekampung dan anak-anak sungainya dari hulu hingga hilir; yang meliputi Kabupaten Lampung Tengah dan Lampung Selatan. Adapun bentukbentuk situs dengan kriteria seperti tersebut di atas, ada sebanyak 8 situs, yakni situs Gelombang, Pejambon Pugung Raharjo, Gedig, Parigi, Cicilik, Meris, dan Bentengsari.

Bahasan ini dimaksudkan untuk melihat pola melalui persebaran situs-situs yang terletak di sepanjang DAS Sekampung. Dengan demikian perlu dibuat suatu kerangka 
ataupun model penelitian yang menggunakan peta sebagai alat peraga untuk memperlihatkan keletakan masing-masing situs di sepanjang sungai tersebut.

\section{Distribusi Situs}

Adapun situs-situs yang diteliti sebagai berikut:

\section{A. Situs Gelombang}

Secara geografis situs ini terltak pada koordinat $50^{\circ} 18^{\prime \prime} 39^{\prime}$ LS dan 104" $43^{\prime \prime}$ BT dengan ketinggian $275 \mathrm{~m} \mathrm{dpl} \mathrm{Situs} \mathrm{ini} \mathrm{terletak} \mathrm{di} \mathrm{daerah} \mathrm{pegunungan} \mathrm{bukit} \mathrm{yang} \mathrm{berorentasi}$ arah Utara-Selatan, di bagian Utara berbatasan langsung dengan lembah sungai Ilahan Pada bagian selatan berbatasan dengan jalan raya Pulau Panggung, Ulubelu. Secara administratif situs ini termasuk dalam wilayah Desa Pulau Panggung, Kecamatan Pulau Panggung, Kabupaten Tanggamus, Lampung Selatan. Nama Gelombang diberikan oleh penduduk setempat untuk menyebut daerah yang permukaannya bergelombang.

Melihat keletakan situs terhadap sungai dapat juga dikatakan, situs Gelombang terletak pada kaki meander sungai Ilahan yang berbentik punggungan bukit. Bentuk situs Gelombang, permukaan tanahnya bergelombang yang pada bagian utara lebih rendah dibandingkan bagian selatan (makin ke selatan makin tinggi/meninggi). Perbedaan tinggi antar gelombang mencapai $10 \mathrm{~m}$ Panjang kemiringan lereng dari sungai kepegunungan tersebut ada $60 \mathrm{~m}$. Permukaan tanah yang bergelombang disebabkan karena adanya 4 buah parit kemungkianan sengaja dibuat/digali yang memotong punggungan bukit tersebut. Lebar parit 2-3 m dengan kedalaman 1,5-2 $\mathrm{m}$. Adanya parit ini membentuk ruang-ruang pada situs tersebut, yang diberi nomor berdasarkan urutan dari tepi sungai. Pada ruang 1 yang terletak di punggungan bukit paling utara ditemukan sebaran artefak tembikar dan keramik 1 buah. Pada ruang 2 ditemukan dolmen dan sebaran batuan disekitarnya. Pada ruang 3 terdapat dolmen berjumlah 3 buah masingmasing berukuran $(100 \times 110 \times 25 \mathrm{~cm}) ;(95 \times 70 \times 15 \mathrm{~cm})$; dan $70 \times 50 \mathrm{~cm})$. Kurang lebih $3 \mathrm{~m}$ ke utara terdapat batu berjajar 3 buah, yang pada bagian permukaannya agak rata dan pada bagian tertentu membentuk ujung dari suatu benda yang mengarah ke utara. Selain terdapat juga temuan-temuan batu-batu bulat kecil atau lonjong dengan berbagai ukuran dengan rata-rata diameter batu $5-10 \mathrm{~cm}$. Temuan lain adalah berupa sebaran artefak yang terdiri dari pecahan tembikar sebanyak 31 buah dan keramik sebanyak 20 buah serta artefak besi. Pada ruang 1 ditemukan pecahan tembikar 3 buah, keramik 1 buah dan fragmen alat batu 2 buah. Hasil analisis pendahuluan keramik dan tembikar menunjukan keramik tersebut berasal dari Cina, Thailand dan Vietnam. Kronologi keramik tersebut menunjukan berasal dari Dinasti Tang abad 10-11 M, SungYuan abad 13-14 M, Thailand dan Vietnam abad 16, Dinasti Ching abad 17-18 M. Dari 
jumlah sampel keramik yang ada maka yang paling banyak berasal dari Dinasti SungYuan abad 13-14 m.

Hasil analisis pendahuluan pada artefak tembikar atas atribut warna, tempar dan tebal menunjukan bentuk yang terdiri dari wadah dan non wadah. Secara umum tembikar yang ditemukan di situs ini mempunyai ketebalan $4 \mathrm{~mm}$. Bentuk non wadah terdiri dari tungku dan tutup Pengamatan atas bahan dan warna menunjukan temper yang kasar (yang terdiri dari pasir yang banyak mengandung silika dengan warna hitam dan coklat dan merahPengamatan pada atribut tehnologi menunjukan tembikar tersebut dibuat dengan cara masih sederhana meskipun sudah menggunakan roda putar dan tatap landasPengamatan atas atribut-atribut tersebut di atas menunjukan bahwa tembikar yang dibakar pada suhu yang rendah $600^{\circ} \mathrm{C}-800^{\circ} \mathrm{C}$.

Dilihat dari hasil kerapatan temuan maka temuan yang paling padat pada ruang 1 , yakni keramik sebanyak 20 buah,dan tembikar sebanyak 33 buah, kerak besi 3 buah dolmen dan batu berjejerPada ruang 3 hanya terdapat 5 buah tembikar dan 1 buah keramik Pada ruang 2 ditemukan dolmen dan sebaran batu yang mengarah pada adanya suatu aktifitas. Pada ruang 3 hanya ditemukan artefak tembikar dan keramik. Keadan ini dapat menunjukan bahwa tingkat aktifitas manusia masa lalu secara intensif dilakukan di ruang 2. Secara keseluruhan situs ini mempunyai luas $2,1 \mathrm{Ha}$. Adanya sebaran batuan besar di situs ini mungkin sekali akibat endapan vulkanik yang diterima dari gunung Tenggamus yang berada di sebelah selatan Situs.

Perlu juga diutarakan bahwa situs gelombang terletak bersebelahan dengan situs Megalitik Batu Bedilhanya dipisahkan oleh lembah aliran Sungai Ilahan dan pegunungan yang mempunyai ketinggian $350 \mathrm{~m}$ dpl, sehingga jaraknya menjadi jauh bila ditempuh dengan jalan kaki Situs BatuBedil tepatnya berada $260^{\circ}$ ke arah Barat Laut dari situs Gelombang. Berkaitan dengan hal tersebut maka kecil kemungkinan untuk saling berhubungan antara kedua situs tersebut dalam jarak tempuh yang singkat.

\section{B. Situs Pejambon}

Secara geografis situs ini terletak pada koordinat $50^{\circ} 14^{\prime} 21^{\prime \prime}$ LS dan $105^{\circ} 7^{\prime} 28^{\prime \prime}$ BT, dengan ketinggian $+50 \mathrm{~m}$ dpl Secara administratif situs ini terletak di Desa Pejambon, Kecamatan Gedongtataan, Kabupaten Lampung Selatan. Dahulu daerah ini disebut Negeri Sipn. Setelah menjadi daerah transmigrasi sejak 1915 penduduk menyebutnya dengan nama PejambonPenduduk transmigrasi membuka lahan ini dengan menanam kelapa sawit. Menurut cerita penduduk setempat pada mulanya tempat ini dihuni oleh orang Pubiyan yang datang dari Gunung Kapuk.Sebagian besar situs ini ditanami pohon kelapa. 
Situs ini terletak pada dataran yang merupakan meander sungai Sekampung, yang mengarah ke Utara-Selatan, tepatnya ditepi sungai Sekampung Aliran sungai Sekampung yang mengarah ke Selatan ini membentuk meander Pada meanderini terdapat gunduka tanah dan parit yang mengarah Barat-Timur yang menghubungkan meander tersebut denga aliran sungai Sekampung. Gundukan tanah parit ini berjumlah 2 buah yang membentuk ruang sebanyak 2 buah yakni ruang 1 berbatasan langsung dengan sungai Sekampung dengan ketinggian $\pm 5 \mathrm{~m}$ dari permukaan air sungai meander ini mempunyai luas $4,1 \mathrm{Ha}$.

Pada ruang I ditemukan keramik 1 buah, dan kerak besi seberat kira-kira 1,5 kg (4 buah). Dari uraian ini dapat diketahui bahwa tingkat aktifitas tertinggi terdapat di ruang 2. Dari artefak yang ditinggalkan dapat diketahui kemungkinan besar adanya pembuatan benda logam di ruang 2 meski masih sederhana. Kegiatan lainnya adalah kegiatan yang berkenaan dengan pemukiman sehari-hari dengan adanya temuan tembikar dan keramik.

\section{Situs Pugung Raharjo}

Secara Geografis situs Pugung Raharjo terletak pada koordinat $50^{\circ} 18^{\prime} 00^{\prime \prime}$ dan $105^{\circ} 33^{\prime}$ BT dengan ketinggian $\pm 50 \mathrm{~m}$ dpl. Situs ini terletak pada suatu dataran yang berjarak \pm $5 \mathrm{~km}$ ke arah timur dari Sungai Sekampung. Secara administratif situs ini berada di belakang museum Pugung Raharjo, Desa Pugung Raharjo, Kecamatan Jabung, Kabupaten Lampung Tengah.

Daerah ini merupakan daerah perkebunan yang subur dengan adanya mata air yang memancar dan mengalir membentuk sungai kecil Pugung, yang airnya mengalir ke sungai utama yakni Sungai Sekampung, Mata air yang banyak tersebar di sini berjumlah tidak kurang dari 9 buah, dan yang paling besar digunakan oleh masyarakat setempat sebagai instalasi air minum yakni terletak di ruang 2 yang berjarak sekitar $100 \mathrm{~m}$. Sedangkan mata air yang lainnya digunakan kolam pemandian, mengairi sawah, air minum, mandi dan cuci.

Secara fisik unit dataran yang dimiliki situs ini adalah dataran bergelombang dengan lapisan atas didominasi oleh batuan basalt dan andesit. Pada lapisan tengah didominasi oleh batuan tefra berbutir halus dan bagian bawah didominasi oleh tefra berbutir kasar.

Gundukan tanah dan parit di situs ini membentuk ruang-ruang terhadap batas alam, yakni sungai luas keseluruan ruang tersebut adalah $20 \mathrm{Ha}$. Ruang-ruang tersebut diberi nomor berdasar urutan dari timur ke barat. Ruang tersebut dapat dibagi menjadi 4 ruang. Lahan pada ruang 1 mempunyai luas $10 \mathrm{Ha}$, ruang 2 mempunyai luas $4 \mathrm{Ha}$, ruang 3 mepunyai luas $6 \mathrm{Ha}$. Pada ruang l, sejak masa transmigrasi sampai sekarang areal ini 
telah digunakan oleh penduduk sebagai pemukiman, namun pada bagian pinggir gundukan dijumpai sebaran artefak keramik dan pecahan tembikar. Pada ruang 2 terdapat 4 buah punden dan menhir dengan ukuran masing-masing punden I terdiri atas 3 teras, yakni undak 1 berukuran $12 \times 12 \mathrm{~m}$, undak ke-2 berukuran, $8 \times 5,8 \mathrm{~m}$, dan undak $\mathrm{ke}-3$ berukuran $3 \times 3 \mathrm{~m}$. Tinggi keseluruhan punden I adalah $3 \mathrm{~m}$. Punden II terdiri dari 3 undak, dengan undak 1 berukuran $12 \times 12 \mathrm{~m}$, undak 2 berukuran $8 \times 8 \mathrm{~m}$ yang mempunyai ketinggian $3 \mathrm{~m}$. Punden III terdiri atas 2 undak Undak 1 berukuran $9 \times 9 \mathrm{~m}$ dan undak 2 berukuran $5 \times 5 \mathrm{~m}$. Tinggi punden ini $1,70 \mathrm{~m}$. Selanjutnya punden IV hanya terdiri dari 1 teras saja yang berukuran $6 \times 6 \mathrm{~m}$ dengan ketinggian $0,60 \mathrm{~m}$. Pada ruang 2 ditemukan sebaran artefak keramik, tembikar dan manik-manik dalam jumlah yang cukup banyak.

Pada ruang 3 terdapat kompleks batu phalus di mana terdapat dolmen dan menhir yang mengelilingi menhir phalus (penduduk setempat menyebutnya batu mayat). Pada bagian depan sejajar dengan "batu mayat" terdapat punden berundak 1 merupakan hasil rekonstruksi oleh Ditlinbijarah Jakarta. Punden tersebut berukuran $6 \times 6 \mathrm{~m}$ dengan ketinggian $0,60 \mathrm{~m}$.

Pada sisi bagian luar dari gundukan tanah dan parit situs Pugung Raharjo terdapat 2 buah punden. Berukuran masing-masing: punden VI yang merupakan punden yang paling besar dengan 3 undak. Pada bagian bawah punden ini dilengkapi dengan parit di seklilingnya, undak ke 1 berukuran $25 \times 25 \mathrm{~m}$, undak ke 2 berukuran $14,8 \times 14,8 \mathrm{~m}$, dan undak ke 3 yang merupakan undak yang tertinggi berukuran $8 \times 8 \mathrm{~m}$. Tinggi punden ini mencapai $7 \mathrm{~m}$. Di sebelah timur punden ini kira-kira berjarak $200 \mathrm{~m}$ terdapat punden VII dengan 2 undak. Ukuran undak ke 1 adalah $9 \times 9 \mathrm{~m}$, sedangkan undak ke 2 berukuran $5,6 \times 5,6 \mathrm{~m}$. Punden ini mempunyai ketinggian $2 \mathrm{~m}$. Di atas punden ini ditemukan arca Bodhisatwa yang duduk di atas lapik, arca ini terdapat batu berlobang dengan berbagai ukuran, kolam, batu lumpang dan batu bergores. Mata air ini mengalir ke sungai kecil Pugung yang airnya mengalir ke sungai Sekampung. Pada sisi selatan menyeberangi sungai kecil tersebut terdapat punden yang diberi nama punden Kemiling Kareng terletak di Desa Kemiling. Punden ini pernah diekskavasi yang menunjukkan adanya temuan bata bertuliskan angka tahun 1287 dengan huruf Jawa Kuno Baru. Selain itu ditemukan pula artefak manik-manik dalam jumlah ratusan.

Bagaimana hubungan arca dengan bukit Kemiling serta gundukan tanah dan parit menimbulkan asumsi bahwa pada masa itu abad ke $13 \mathrm{M}$ pemukiman yang terletak di luar gundukan tanah dan parit termasuk punden yang tersebar telah digunakan. Boleh jadi bangunan berundak tersebut merupakan prototipe dari awal pembuatan suatu bangunan suci Hindu-Bhuda berupa candi. Sedangkan pemukiman di dalam gundukan tanah dan parit digunakan pada masa sebelum itu. 


\section{Situs Gedig.}

Secara geografis Gedig terletak pada koordinat $050^{\circ} 28^{\prime} 16^{\prime \prime}$ LS dan $105^{\circ} 40^{\prime} 0 \mathrm{I}^{\prime \prime} \mathrm{BT}$. Situs ini terletak pada dataran rendah meander sungai Sekampung yang merupakan daerah subur. Daerah ini oleh orang-orang "Trans" sejak dulu ditanami, dijadikan areal perkebunan kopi, vanili, dan kelapa. Sebelah barat situs ini berbatasan langsung dengan sungai Sekampung. Di antara sungai dan situs tersebut terdapat lereng-lereng dengan kemiringan $45-60 \%$.

Secara administratif situs ini termasuk dalam wilayah Desa Negarasaka, Kecamatan Jabung, Kabupaten Lampung Tengah. Bentuk situs ini mengikuti pola aliran Sungai Sekampung. Pada bagian depan situs ini berbatasan langsung dengan jalan raya JabungPugung. Pada bagian tepi jalan tersebut terdapat SD Negarasaka, di belakang sekolah kira-kira 50-100 m terdapat gundukan tanah dan parit yang berbatasan langsung dengan rawa dan Sungai Sekampung. Oleh masyarakat daerah tersebut dinamakan juga dengan batu lesung, sedangkan gundukan tanah yang ada disebut masyarakat sebagai Siring Oleh karena itu daerah ini sering disebut daerah batu lesung.

Melihat bentuk denah gundukan tanah dan parit, mudah diduga situs ini mempunyai 2 ruangan. Ruang 1 diberi nomor dari kiri ke kanan atau dari jarak terdekat dengan sungai ke daratan, untuk memudahkan deskripsi dan pengolahan data. Pada ruang 1 terdapat mata air yang airnya mengalir ke Sungai Sekampung. Selain itu terdapat pula sebaran artefak lepas berupa pecahan keramik dan tembikar, masing-masing berjumlah 119 dan 155 buah. Pada ruang 2 terdapat makam dan punden dengan sebaran artefak yang tingkat kerapatannya sedang dan juga dijumpai tembikar yang berhias. Hiasan tersebut terdiri dari hiasan dengan teknik gores, pola tali dan cetak. Selain itu juga dijumpai adanya dolmen besar dengan sebaran batu-batu besar seperti dolmen juga terhampar di tanah. Pada bagian luar dari nuang 1 dan 2, terdapat punden-punden dengan berbagai ukuran. Pada bagian luar dekat rawa terdapat punden yang puncaknya terdapat dolmen yang bagian atasnya terdapat lubang dengan ukuran diameter $35 \mathrm{~cm}$ dan kedalaman lubang $18 \mathrm{~cm}$. Jumlah keseluruan punden-punden tanah dan parit, tidak kurang dari 10 buah punden.

Dari pengamatan terhadap denah dan tata letak gundukan tanah dan parit dapat diduga bahwa pada ruang di mana terdapat dolmen, gimik, dan makam Islam masa sekarang, diperlukan sebagai tempat kegiatan yang bersifat ritual. Scdangkan tempat lainnya seperti punden di sebelah luar gundukan tanah dan parit ataupun di ruang 1 sebagai tempat kegiatan ritual di luar gundukan, kadang-kadang juga dilakukan yakni di punden dekat rawa di mana pada puncaknya terdapat dolmen yang pada bagian atasnya terdapat sebuah lubang yang cukup besar, yang diperkirakan sebagai tempat meletakan sesaji. Ukuran dolmen adalah 1,60 m x 1,65 m dan ukuran lubang sbb: keliling lingkaran atas $28 \mathrm{~cm}$ dengan kedalaman $20 \mathrm{~cm}$. 


\section{E. Situs Parigi}

Secara geografis situs ini terletak pada koordinat $05^{\circ} 27^{\prime} 51^{\prime \prime}$ LS dan $105^{\circ} 40^{\prime} 13^{\prime \prime} B T$ dengan ketinggian sekitar $50 \mathrm{~m}$ dpl. Letak situs ini sejajar dengan situs Gedig dan berjarak sekitar $800 \mathrm{~m}$ ke arah utara. Dari Sungai Sekampung situs ini berada di sebelah timur dengan jarak $1 \mathrm{Km}$. Secara administratif situs ini berada di ladang bapak Ismail termasuk wilayah Desa Jabung, Kecamatan Jabung, Kabupaten Lampung Tengah. Penduduk sering menyebut situs ini dengan benteng Nuana.

Sama dengan Situs Gedig, situs Perigi juga termasuk dalam jalur bentang alam meander sungai yang mempunyai jalur sungai-sungai besar dengan tanggul lebar. Situs ini mempunyai kemiringan lereng kurang dari $2 \%$. Bentuk situs ini berdenah segi empat yang pada keempat sisinya terdapat gundukan tanah dan parit. Tinggi gundukan tanah mencapai 5-7 m dan kedalaman parit mencapai 2-4 m. Situs ini mempunyai ukuran luas $2,6 \mathrm{Ha}$. Pada beberapa bagian parit sudah menjadi landai sebagai akibat aktivitas manusia sekarang. Situs ini seolah terbagi menjadi dua jalan kampung yang membelah situs tersebut pada waktu program AMD (Abri Masuk Desa). Sebagai wilayah Jabung yang dikenal penghasil lada, vegetasi didominasi oleh tanaman lada, sedangkan tanaman lainnya kelapa, salak, vanili, kopi, dll.

Dengan denah yang sederhana ini yakni segi empat, situs Perigi hanya mempunyai 1 ruang saja di dalam gundukan tanah dan parit tersebut terdapat batu berjajar dan menhir berbentuk phalus yang kini sudah terbagi 3 akibat sering dijadikan tiang pancang sapi oleh penduduk. Penduduk menyebut batu berjajar ini dengan batu kelintang karena berbentuk seperti alat musik pukul kelintang.

Batu berjajar adalah susunan batu tunggal besar yang berjajar utara-selatan yang pada bagain tertentu terdapat menhir. Tinggi menhir berbentuk phalus ini mencapai $180 \mathrm{~cm}$ dengan diameter $43 \mathrm{~cm}$. Batu berjajar tersebut mempunyai ukuran panjang mencapai 22 $\mathrm{cm}$. Di dalam ruang ini tidak ditemukan artefak lepas.

Pada bagian luar dekat parit arah di bagian utara dan timur terdapat batu berjajar yang melihat bentuknya disebut dengan "batu berjajar". Pada bagian ini juga terdapat punden dari tanah yang mengandung sebagian batu antara lain 2 buah berada sebelah utara, 2 buah berada di sebelah timur dan 2 buah di sebelah selatan. Ukuran rata-rata punden adalah lingkaran dengan garis tengah 9-11 m. Di luar ruang ditemukan artefak lepas berupa pecahan keramik sebanyak 2 buah dan fragmen alat logam 1 buah.

Berkaitan dengan keletakan, denah dan temuan di atas dapat diketahui bahwa situs Perigi tidak dihuni dalam waktu yang cukup lama. Daerah ini hanya dimukimi secara temporer, mungkin sekali hanya pada saat melakukan kegiatan ritual keagamaan saja. Hal ini dibuktikan dengan temuan batu berjajar dan menhir phalus di dalam ruang dan 
batu berjajar lainnya serta punden di luar ruang, selain itu tidak ditemukannya sisa-sisa kegiatan yang dibuktikan dengan adanya artefak lepas seperti tembikar, keramik dan sisa alat" keseharian; lainnya.

\section{F. Situs Meris}

Secara geografis situs ini terletak pada koordinat $05^{\circ} 30^{\prime} 29^{\prime \prime}$ LS dan $105^{\circ} 40^{\prime} 59^{\prime \prime}$ BT dengan ketinggian $\pm 54 \mathrm{~m}$ dpl. Situs ini berjarak $400 \mathrm{~m}$ dari Sungai Sekampung ke arah barat. Secara administratif situs yang terletak di tepi jalan raya yang menghubungkan daerah Pugung Raharjo dengan kota kecamatan Jabung, termasuk wilayah Desa Asahan, Kecamatan Jabung,Kabupaten Lampung Tengah.

Situs ini mempunyai bentuk tidak beraturan, di sebelah barat berbatasan langsung dengan rawa Meris dan di sebelah utara dan timur berbatasan dengan jalan kampung yang menghubungkan situs tersebut dengan jalan raya. Pada bagian selatan situs ini dikelilingi dengan rawa. Tepat di sebelah rawa terdapat Sungai Sekampung. Gundukan tanah dan parit yang ada hanya pada bagian utara dan timur. Pada beberapa bagian parit ini menjadi landai dan cenderung datar, sejajar dengan permukaan tanah sekarang sebagai akibat dari pengerjaan perkebunan. Sejak tahun 1977 situs ini hanya mempunyai 1 ruang saja. Pada bagian dalam terdapat punden persegi yang sekarang sudah hampir rata dengan tanah dengan sebaran batu-batu yang masih tersisa. Melihat sebarannya agaknya batu-batu ini mempunyai bentuk seperti denah sebuah makam dari masa Islam dengan orientasi utara-selatan. Selain itu bagian barat terdapat sebaran batu besar seperti dolmen yang melihat bentuknya seperti batu kandang. Pada bagian ini banyak ditemukan pecahan tembikar dan sedikit keramik.

Pada bagian luar dekat rawa terdapat 2 buah punden yang masing-masing berukuran diameter $8 \times 5 \mathrm{~cm}$ dan $3 \times 3 \mathrm{~cm}$. Persis di sebelah timur punden yang besar, berjarak kurang dari $1 \mathrm{~m}$ terdapat makam yang ditandai dengan susunan batu yang berbentuk kotak-kotak yang berorientasi utara-selatan. Di sekitar punden ini yang berbatasan langsung dengan Sungai Sekampung banyak ditanami jagung. Pada saat penelitian berlangsung bagian tertentu dari ladang tersebut baru saja dibersihkan dengan cara dibakar, sehingga banyak artefak lepas muncul di permukaan. Artefak terscbut antara lain, kapak batu (1 buah), keramik dalam jumlah sedikit, sebaliknya pecahan tembikar dijumpai dalam jumlah yang cukup banyak. Temuan lainnya adalah kerak besi dengan perkiraan berat $0,5 \mathrm{~kg}$. Adapun bentuk tembikar tersebut berdasarkan analisis pendahuluan adalah tungku, tempayan, cucuk kendi, tutup kendi, pelandas (anvil) dan bentuk wadah lainnya.

Berkaitan uraian di atas dapat diketahui bahwa intensitas aktivitas manusia paling banyak dilakukan di luar gundukan tanah dan parit yang menjadi pertanyaan adalah di 
mana mereka bermukim ketika musim hujan tiba di mana daerah tersebut terendam air selunuhnya. Daerah ini merupakan daerah banjir dengan morfologi rawanya. Sehingga apabila musim hujan daerah ini terendam air yang berasal dari sungai Sekampung dan air rawa itu sendiri. Adanya gundukan tanah dan parit di situs ini mampu mencegah air masuk ke dalam ruang situs, dengan demikian boleh jadi pada waktu musim hujan tiba mereka menempati bagian dalam ruang, sebaliknya pada musim kemarau lahan bagian luarlah yang digunakan. Sementara itu kegiatan pertanian bisa tetap belangsung. Keterangan ini menunjukkan bahwa mereka menggunakan bagian dalam dan luar ruang untuk beraktivitas berdasarkan musim yang berlaku. Hal ini juga dibuktikan pada bagian dalam ruang terdapat makam yang denah dan bentuknya mempunyai kesamaan dengan makam yang terdapat pada bagian luar.

\section{G. Situs Cicilik}

Secara geografis situs ini terletak pada koordinat $05^{\circ} 29^{\prime} 56^{\prime \prime}$ LS dan $105^{\circ} 40^{\prime} 52^{\prime \prime}$ BT dengan ketinggian $\pm 23 \mathrm{~m}$ dpl. Situs ini terletak di sebelah timur anak Sungai Sekampung dengan jarak $\pm 1 \mathrm{~km}$. Secara administratif situs Cicilik termasuk dalam wilayah Desa Asahan, Kecamatan Jabung, Kabupaten Lampung Tengah Nama asli desa ini adalah Pangkauan Ratu atau Desa Tiuhlom.

Situs ini dikelilingi oleh rawa yang mempunyai mata air. Situs ini dibangun di daerah rawa yang merupakan daratan yang cukup luas. Dengan membuat parit. Parit yang digali berbatasan langsung dengan rawa dan timbunan tanah yang dihasilkan ditumpuk disalah satu sisi saja yang luasnya kira-kira $1 \mathrm{Ha}$. Pada sisi bagian dalam terdapat batu kandang yang merupakan hamparan batu monolit besar, yang terdiri dari dolmen ataupun altar batu. Di sekitar batu kandang ini ditemukan sebaran keramik, pecahan tembikar, manik-manik, artefak logam, dan kerak besi. Letak batu kandang di sebelah utara dan timurlaut berbatasan langsung dengan parit yang merupakan bagian rendah. Sebaran artefak yang dijumpai disini umumnya berukuran kecil. Hal ini diduga sebagai akibat dari proses erosi yang membawa material tersebut ke bagian yang rendah yakni dekat rawa. Komposisi temuan yang ada didominasi oleh pecahan tembikar. Jumlah sampel pecahan tembikar hasil survai ada 152 buah, keramik berjumlah 119 buah, manik-manik berjumlah 3 buah berwarna biru dan coklat, kerak besi kurang lebih seberat $1 \mathrm{~kg}$ dan lelehan besi kecil-kecil sebanyak 12 buah seberat $200 \mathrm{gr}$.

Pada sisi bagian luar terdapat 3 buah punden yang terletak di sebelah utara dan timur. Punden tersebut terbuat dari tanah yang diberi penguat dengan batu pada bagian pinggirnya. Pada saat ditemukan nampak batu-batu tersebut berserakan pada bagian atas dan pinggir punden. Ukuran punden tersebut masing-masing punden 1 berdiameter $9 \mathrm{~m}$; punden 2 berdiameter $9 \mathrm{~m}$; dan punden 3 yang terletak pada sisi bagian timur 
batu berjajar lainnya serta punden di luar ruang, selain itu tidak ditemukannya sisa-sisa kegiatan yang dibuktikan dengan adanya artefak lepas seperti tembikar, keramik dan sisa alat" keseharian; lainnya.

\section{F. Situs Meris}

Secara geografis situs ini terletak pada koordinat $05^{\circ} 30^{\prime} 29^{\prime \prime}$ LS dan $105^{\circ} 40^{\prime} 59^{\prime \prime}$ BT dengan ketinggian $\pm 54 \mathrm{~m}$ dpl. Situs ini berjarak $400 \mathrm{~m}$ dari Sungai Sekampung ke arah barat. Secara administratif situs yang terletak di tepi jalan raya yang menghubungkan daerah Pugung Raharjo dengan kota kecamatan Jabung, termasuk wilayah Desa Asahan, Kecamatan Jabung,Kabupaten Lampung Tengah.

Situs ini mempunyai bentuk tidak beraturan, di sebelah barat berbatasan langsung dengan rawa Meris dan di sebelah utara dan timur berbatasan dengan jalan kampung yang menghubungkan situs tersebut dengan jalan raya. Pada bagian selatan situs ini dikelilingi dengan rawa. Tepat di sebelah rawa terdapat Sungai Sekampung. Gundukan tanah dan parit yang ada hanya pada bagian utara dan timur. Pada beberapa bagian parit ini menjadi landai dan cenderung datar, sejajar dengan permukaan tanah sekarang sebagai akibat dari pengerjaan perkebunan. Sejak tahun 1977 situs ini hanya mempunyai 1 ruang saja. Pada bagian dalam terdapat punden persegi yang sekarang sudah hampir rata dengan tanah dengan sebaran batu-batu yang masih tersisa. Melihat sebarannya agaknya batu-batu ini mempunyai bentuk seperti denah sebuah makam dari masa Islam dengan orientasi utara-selatan. Selain itu bagian barat terdapat sebaran batu besar seperti dolmen yang melihat bentuknya seperti batu kandang. Pada bagian ini banyak ditemukan pecahan tembikar dan sedikit keramik.

Pada bagian luar dekat rawa terdapat 2 buah punden yang masing-masing berukuran diameter $8 \times 5 \mathrm{~cm}$ dan $3 \times 3 \mathrm{~cm}$. Persis di sebelah timur punden yang besar, berjarak kurang dari $1 \mathrm{~m}$ terdapat makam yang ditandai dengan susunan batu yang berbentuk kotak-kotak yang berorientasi utara-selatan. Di sekitar punden ini yang berbatasan langsung dengan Sungai Sekampung banyak ditanami jagung. Pada saat penelitian berlangsung bagian tertentu dari ladang tersebut baru saja dibersihkan dengan cara dibakar, sehingga banyak artefak lepas muncul di permukaan. Artefak tersebut antara lain, kapak batu (1 buah), keramik dalam jumlah sedikit, sebaliknya pecahan tembikar dijumpai dalam jumlah yang cukup banyak. Temuan lainnya adalah kerak besi dengan perkiraan berat $0,5 \mathrm{~kg}$. Adapun bentuk tembikar tersebut berdasarkan analisis pendahuluan adalah tungku, tempayan, cucuk kendi, tutup kendi, pelandas (anvil) dan bentuk wadah lainnya.

Berkaitan uraian di atas dapat diketahui bahwa intensitas aktivitas manusia paling banyak dilakukan di luar gundukan tanah dan parit yang menjadi pertanyaan adalah di 
mana mereka bermukim ketika musim hujan tiba di mana daerah tersebut terendam air seluruhnya. Daerah ini merupakan daerah banjir dengan morfologi rawanya. Sehingga apabila musim hujan daerah ini terendam air yang berasal dari sungai Sekampung dan air rawa itu sendiri. Adanya gundukan tanah dan parit di situs ini mampu mencegah air masuk ke dalam ruang situs, dengan demikian boleh jadi pada waktu musim hujan tiba mereka menempati bagian dalam ruang, sebaliknya pada musim kemarau lahan bagian luarlah yang digunakan. Sementara itu kegiatan pertanian bisa tetap belangsung. Keterangan ini menunjukkan bahwa mereka menggunakan bagian dalam dan luar ruang untuk beraktivitas berdasarkan musim yang berlaku. Hal ini juga dibuktikan pada bagian dalam ruang terdapat makam yang denah dan bentuknya mempunyai kesamaan dengan makam yang terdapat pada bagian luar.

\section{G. Situs Cicilik}

Secara geografis situs ini terletak pada koordinat $05^{\circ} 29^{\prime} 56^{\prime \prime}$ LS dan $105^{\circ} 40^{\prime} 52^{\prime \prime}$ BT dengan ketinggian $\pm 23 \mathrm{~m} \mathrm{dpl}$. Situs ini terletak di sebelah timur anak Sungai Sekampung dengan jarak $\pm 1 \mathrm{~km}$. Secara administratif situs Cicilik termasuk dalam wilayah Desa Asahan, Kecamatan Jabung, Kabupaten Lampung Tengah Nama asli desa ini adalah Pangkauan Ratu atau Desa Tiuhlom.

Situs ini dikelilingi oleh rawa yang mempunyai mata air. Situs ini dibangun di daerah rawa yang merupakan daratan yang cukup luas. Dengan membuat parit. Parit yang digali berbatasan langsung dengan rawa dan timbunan tanah yang dihasilkan ditumpuk disalah satu sisi saja yang luasnya kira-kira $1 \mathrm{Ha}$. Pada sisi bagian dalam terdapat batu kandang yang merupakan hamparan batu monolit besar, yang terdiri dari dolmen ataupun altar batu. Di sekitar batu kandang ini ditemukan sebaran keramik, pecahan tembikar, manik-manik, artefak logam, dan kerak besi. Letak batu kandang di sebelah utara dan timurlaut berbatasan langsung dengan parit yang merupakan bagian rendah. Sebaran artefak yang dijumpai disini umumnya berukuran kecil. Hal ini diduga sebagai akibat dari proses erosi yang membawa material tersebut ke bagian yang rendah yakni dekat rawa. Komposisi temuan yang ada didominasi oleh pecahan tembikar. Jumlah sampel pecahan tembikar hasil survai ada 152 buah, keramik berjumlah 119 buah, manik-manik berjumlah 3 buah berwarna biru dan coklat, kerak besi kurang lebih seberat $1 \mathrm{~kg}$ dan lelehan besi kecil-kecil sebanyak 12 buah seberat $200 \mathrm{gr}$

Pada sisi bagian luar terdapat 3 buah punden yang terletak di sebelah utara dan timur. Punden tersebut terbuat dari tanah yang diberi penguat dengan batu pada bagian pinggirnya. Pada saat ditemukan nampak batu-batu tersebut berserakan pada bagian atas dan pinggir punden. Ukuran punden tersebut masing-masing punden 1 berdiameter $9 \mathrm{~m}$; punden 2 berdiameter $9 \mathrm{~m}$; dan punden 3 yang terietak pada sisi bagian timur 
mempunyai ukuran diameter $10 \mathrm{~m}$. Artefak lepas yang ditemukan di sekitar punden adalah pecahan tembikar dan kereweng.

Keadaan situs ini sekarang merupakan areal perkebunan dengan dominasi tanaman lada, kelapa, dan kopi. Dari temuan fitur dan sebaran artefak yang ada dapat diketahui bahwa lahan yang digunakan untuk pemukiman adalah sisi luar dan dalam dari ruang tersebut. Hanya saja jenis aktivitas yang dilakukan berbeda. Tempat yang kecil kurang memungkinkan untuk membuat punden di sisi bagian dalam, karena itu punden yang dibangun dialokasikan pada sisi bagian luar pada bagian yang kering dari daerah rawa tersebut. Sedangkan kegiatan keseharian lainnya berdasarkan temuan artefak yang dilakukan di dalam ruang boleh jadi kegiatan perkebunan dengan sifat tanaman tertentu dilakukan dekat dengan lokasi tempat tinggal yakni di dalam ruangan. Hal ini dilakukan selain merupakan kontrol agar lebih mudah mengawasi tanaman juga untuk melindungi tanaman itu sendiri dari genangan air rawa pada musim hujan.

\section{H. Situs Bentengsari}

Secara geografis situs ini terletak pada koordinat $05^{\circ} 29^{\prime} 42^{\prime \prime}$ LS dan $105^{\circ} 42^{\prime} 48^{\prime \prime}$ BT dengan ketinggian $\pm 64 \mathrm{~m}$ dpl. Situs ini terletak dekat dengan pabrik air minuman mineral 'Aqua' yang menyedot air dari dalam tanah. Secara administratif situs Bentengsari termasuk dalam wilayah Desa Bentengsari, Kecamatan Jabung, Kabupaten Lampung Tengah. Secara keseluruhan daerah ini dikelilingi oleh gundukan tanah dan parit memanjang, membentuk suatu ruang yang seolah-olah membatasi suatu lahan tertentu. Penduduk menyebutnya dengan benteng, oleh karena itu desa ini dinamakan Bentengsari.

Situs ini terletak di DAS Sekampung, yaitu di dataran bagian atas yang kering pada daerah rawa. Di situs ini tidak dijumpai mata air akan tetapi daerah ini banyak mengandung air tanah. Genangan air tanah ini menyatu dengan air rawa membentuk sungai kecil yang airnya mengalir ke Sungai Sekampung. Masyarakat setempat menyebutnya sungai Umbungan. Air rawa itu sendiri mendapat aliran air dari Danau Bulia yang berjarak $6 \mathrm{~km}$ dari situs tersebut. Air yang mengalir dari Danau Bulia ini masuk ke dalam rawa, menyatu dengan Sungai Umbungan, yang aimya mengalir ke Sungai Sekampung. Daerah yang banyak mengandung air tanah ini sangat cocok untuk kegiatan pertanian seperti kopi, kelapa, coklat, dan karet. Daerah rawa tersebut menerima endapan vulkanik dari Gunung Tanggamus, yang menyebabkan daerah itu menjadi dataran yang cukup tinggi dan subur. Keadaan ini dibuktikan dengan adanya temuan mangkuk keramik utuh pada kedalaman $2 \mathrm{~m}$, oleh bapak Yasin ketika sedang menggarap tanah. 
Gundukan tanah dan parit yang memanjang menbentuk satu ruangan yang cukup besar, berbatasan langsung dengan rawa di sebelah selatannya. Gundukan tanah dan parit ini mempunyai bentuk bentang alam yang ada sehingga mempunyai kesan tidak beraturan. Di dalam ruang tersebut ditemukan sebaran batu berlubang yang sekarang terkonsentrasi di bawah pohon besar di tepi jalan masuk sekarang ke dalam ruang tersebut. Batu berlubang dan batu dakon itu dikumpulkan masyarakat setempat dari daerah sekitanya di dalam ruangan, baik di tepi sungai kecil maupun dekat gundukan. Temuan lainnya adalah 4 buah makam panjang, 3 diantaranya berukuran hampir sama yakni $450 \times 90 \times 30 \mathrm{~cm} ; 650 \times 90 \times 25 \mathrm{~cm} ; 410 \times 100 \times 30 \mathrm{~cm}$, satu di antara makam tersebut berukuran agak panjang yakni: $200 \times 70 \mathrm{~cm}$. Artefak lepas banyak ditemukan dalam ruang ini antara lain keramik dari Cina, Vietnam, dan Thailand dalam jumlah ribuan dan persebaran yang padat. Adapun kronologi keramik tersebut antara lain masa Dinasti Sung-Yuan abad 13-14 M, Vietnam dan Thailand abad 15-16 M, dan Ming abad 17-18 M. Temuan lainnya adalah pecahan tembikar, kerak besi, mata uang, dsb. Pada bagian luar dari ruang tersebut dijumpai 2 buah punden masing-masing mempunyai diameter utara-selatan $8,7 \mathrm{~m}$, diameter timur-barat $7,40 \mathrm{~m}$. Pada punden 1 dijumpai kerak besi cukup banyak sejumlah $3 \mathrm{~kg}$. Punden 2 terletak di depan pabrik air mineral 'Aqua' teras pertama berukuran $11 \times 11 \mathrm{~m}$ dan teras kedua berukuran $9 \times 9 \mathrm{~m}$. Pada bagian atas punden teredapat makam yang bernisan menhir dengan orientasi utara-selatan. Makam Islam ini dikenal dengan nama makam Salah Perintah.

Hasil pengamatan pada artefak kerak besi menunjukkan bahwa penduduk situs Bentengsari sudah mengenal logam. Pengerjaan logam dikerjakan dengan teknik tuang dan tempa meskipun masih sangat sederhana. Hal ini terlihat dari bongkah-bongkah besi yang merupakan bekas lelehan yang sudah mengeras. Mudah diduga bahwa bentuk lelehan ini tidak beraturan, akibat dari jejak yang ditinggalkan manusia masa lalu dalam pengerjaan logam dengan teknik tuang. Pada pengerjaan dengan teknik tempa, jejak yang ditinggalkan adalah sisa logam berupa lempeng-lempeng yang tersusun lapis demi lapis sebagai akibat dari proses tempa.

Berkaitan dengan konteks temuan di atas ada kecenderungan adanya intensitas kegiatan sehari-hari banyak dilakukan dalam ruang, sedangkan di luar nuang terdapat juga kegiatan hanya intensitasnya tidak setinggi di dalam ruangan. Dengan adanya punden dan kerak besi dalam jumlah yang cukup banyak di luar ruangan, maka ada jenis kegiatan lain yang secara intensif dilakukan di luar ruang, yakni kegiatan pemujaan dan penuangan logam.

Berkaitan dengan kondisi geografis situs ini yang sangat subur sebagai akibat endapan aluvial vulkanik, situs ini terus digunakan sampai sekarang untuk pertanian, beberapa diantaranya bahkan dijadikan areal pemukiman penduduk pada masa kini. Keadaan yang subur dan merupakan dataran yang agak tinggi dari rawa di sekitarnya ini memungkinkan orang untuk memilih daerah tersebut sebagai tempat untuk bermukim. 
Akan halnya punden-punden tersebut, penduduk menyebutnya dengan 'Gumuk' atau 'Punjung' yang memang sudah ada sebelum orang-orang tersebut menetap di situs Bentengsari.

\section{Pembahasan}

Secara Geografis situs-situs tersebut terletak di DAS Sekampung, hal ini pulalah yang menjadi dasar batas kajian ruang atas situs-situs ini. Analisis peta-peta dasar menyatakan beberapa informasi tentang keletakan situs secara akurat dan kerincian data tentang lingkungan masing-masing situs.

Ada baiknya disebutkan peta-peta yang telah dianalisis yang telah menghasilkan beberapa informasi yang kita inginkan Peta-peta tersebut antara lain:

Peta US Army Map Service, Far East Compiled 1960 skala 1:100.000 dengan nomor lembar sbb: 4125 (Djabung), 4127 (Sukadana), 4026 (Teluk Betung), 027 (Mandah), 3926 (Kota Agung), dan 3927 (Negeri Kapanjungan).

Peta geologi lembar Tanjung Karang (no. 1110) dan lembar Kota Agung (no. 1010) skala 1:250.000 - Puslitbang Geologi Bandung 1993.

Peta topografi lembar Kota Agung (no. 1010) dan Tanjung Karang (no. 1110).

Peta Tataguna Lahan lembar Kota Agung (no. 1010) dan Tanjung Karang (no. 1110).

Adapun informasi yang diperoleh adalah koordinat, keletakan terhadap sungai, luas, satuan bentang lahan, sebaran temuan, tata letak, dlsb. Dari ke-8 (delapan) situs-situs tersebut yang terletak di daerah hulu adalah situs Gelombang, terletak paling hilir adalah situs Bentengsari. Dilihat dari bentang alam (landsekap) situs ini teletak jauh dari sungai Sekampung akan tetapi apabila ditarik garis atau batas. DAS maka situs ini bisa dimasukkan dalam wilayah DAS Sekampung Wilayah DAS Sekampung itu sendiri ada pada koordinat antara $5^{\circ} 10^{\prime}-5^{\circ} 40^{\prime} \mathrm{LS}$ dan $104^{\circ} 30^{\prime}-105^{\circ} 50^{\prime} \mathrm{BT}$.

Dari delapan situs tersebut apabila dilihat di atas peta DAS Sekampung, maka terlihat ada pola persebaran yang mengelompok dan menyebar. Hal ini diperlihatkan pada keletakan fisik situs-situs tersebut terhadap DAS, yakni situs Gielombang terletak pada daerah hulu, yakni di wilayah Lampung bagian Selatan. Situs Pejambon terletak pada bagian tengah. Sedangkan pada bagian hilir terdapat 2 (dua) macam pola persebaran, yaitu menycbar dan mengelompok. Pola keletakan mengelompok diwakili oleh situs- 
situs Parigi, Gending, Bentengsari, Cicilik, dan Meris Pola keletakan menyebar diwakili oleh situs Gelombang, Pejambon dan Pugung Raharjo.

Dilihat dari bentuk dan teknik pembuatannya situs-situs tersebut mempunyai sedikitnya 2 (dua) unsur, yakni gundukan tanah dan parit Namun demikian ada pula yang mempunyai 1 (satu) unsur saja, yakni parit saja seperti halnya pada situs Gelombang.

Adapun bentuk pemukiman di DAS Sekampung dapat dikategorikan atas 2 (dua) kelompok, yakni pemukiman yang bergundukan tanah dan parit dan yang tidak. Hal yang disebut belakangan ini diwujudkan dengan tinggalan-tinggalan arkeologis lainnya. Punden yang pada bagian atasnya terletak menhir, seperti halnya di situs Sidomukti dan situs Balung Jero di daerah Lampung Tengah.

Situs lainnya adalah situs yang ditandai dengan temuan sebaran keramik yang cukup luas $+1 \mathrm{Ha}$, dan situs Batu Budak, yang ditandai dengan temuan batu bergores di tepi sungai Sekampung. Dan pada bagian atasnya (daratan yang agak tinggi) terdapat makam-makam kuno. Hasil ekskavasi menunjukkan adanya temuan rangka, yang memperlihatkan sikap atau cara-cara penguburan dari masa Islam. Pada bagian lapisan di atasnya ditemukan tembikar dan keramik asing.

\section{A. Hubungan Antarsitus}

Melihat denah tiap-tiap situs, maka setiap situs mempunyai ciri-ciri peninggalan dari tradisi megalitik seperti punden, dolmen, batu berjajar, batu berlobang, batu bergores, dan batu-batu lainnya yang terlihat merupakan hasil pangkasan manusia, yang biasanya tersusun dari wadah di tanah, dan gumuk atau tanah yang ditinggikan berbentuk kerucut. Gundukan tersebut biasanya bila dibuka merupakan sebuah punden, atau gundukan itu sendiri merupakan punden yang bertingkat. Namun beberapa (karena dimakan usia) bagian-bagian kerucut tertinggi banyak yang telah menjadi landai hingga menyerupai gundukan tanah biasa. Hal ini dibuktikan lagi dengan adanya gundukan tanah yang bagian bawahnya disangga oleh batu-batuan sebagai penguat ataupun batas undakan. Di sekitar tinggalan tersebut ditemukan sebaran tembikar, keramik ataupun manik-manik, dll.

Ada situs yang di dalam ruangnya terdapat batu berjajar dan menhir akan tetapi tidak ditemukan artefak lainnya, seperti pada situs Parigi. Situs Parigi merupakan satusatunya situs yang bentuknya beraturan, yakni segi empat. Di sisi bagian luar dari situs ini terdapat punden dan batu berjajar. Adapun situs yang didalamnya, luarnya tidak ditemukan punden melainkan ditemukan dolmen yang berukuran cukup besar. Pada ruang-ruang tertentu ditemukan sebaran artefak yang cukup banyak, namun ada juga salah satu ruang yang tidak mengandung temuan artefak apapun. Seperti halnya pada 
situs Gelombang yang terletak pada bagian hulu sungai Sekampung. Situs Pugung Raharjo merupakan situs paling besar $(21 \mathrm{Ha})$ dengan gundukan tanah yang besar dan paritnya pun cukup dalam, sedangkan punden-pundennya ditemukan dalam keadaan tersebar, ada yang terdapat di dalam dan di luar ruang. Punden yang terdapat di luar ruang sangat besar, mencapai ketinggian $7 \mathrm{~m}$, dengan luas teras pertama $25 \times 25 \mathrm{~m}$. Pada ruang II (lihat peta) terdapat batu kandang yang di tengahnya terdapat menhir yang disebut oleh beberapa peneliti maupun masyarakat sebagai batu mayat (Sukendar, 1976).

Dari uraian mengenai contoh beberapa situs di atas nampak bahwa situs Pugung Raharjo merupakan situs yang paling besar dari segi ukuran dan keragaman temuannya. Sebagai misal ada 17 buah punden yang terdapat di sini, begitu pula dengan temuan keramik, tembikar, bahan pembuat manik-manik dan manik-manik, bahkan di sini juga ditemukan kerak besi, artefak besi dan artefak batu lepas, seperti kapak batu.

Adanya tata letak terhadap situs yang dekat dengan sumber air dengan Sungai Sekampung sebagai sungai utama, dan parit besar yang sengaja dibuat, maka diduga kuat mereka berhubungan dengan menggunakan transportasi air. Hal ini dibuktikan lagi dengan cerita masyarakat setempat (Pak Yasin) yang mengatakan pernah ditemukan perahu di situs Bentengsari di parit yang menghubungkan ruang bagian dalam dengan rawa dan sungai. Dugaan sementara adalah bahwa hubungan yang terjadi adalah hubungan dagang, dengan manik-manik dan keramik sebagai barang komoditi. Apabila ditarik garis DAS dari hulu hingga hilir, situs-situs tersebut mempunyai periode yang sama yakni masa megalitik. Dengan demikian bisa dikatakan bahwa situs Pugung Raharjo sebagai pusat kegiatan dari situs-situs serupa yang tersebar di sepanjang DAS Sekampung.

\section{B. Hubungan Situs dengan Unsur-unsur Lingkungan Alam}

Unsur-unsur lingkungan yang menjadi pokok perhatian adalah lingkungan alam yang berkaitan dengan DAS yaitu meliputi bentang lahan, jenis tanah, dan tata guna lahan. Dalam bahasan ini variabel tersebut dikemukakan secara umum berdasarkan analisis hubungan antar ketiga variabel tersebut. Pertimbangan lainnya adalah terbatasnya waktu penulisan.

Dari gambaran fisiografis Sekampung diketahui bahwa Daerah Aliran Sungai (DAS) Sekampung mempunyai variasi ketinggian $0 \mathrm{~m}$ dpl di garis pantai sampai ketinggian $2100 \mathrm{~m} \mathrm{dpl}$ di Gunung Tanggamus. Ketinggian tersebut menunjukkan perbedaan bentang alam mulai dari bagian barat yaitu hulu sungai Sekampung yang berasal dari bukit Tangkil Ulu Sekampung $1375 \mathrm{~m} \mathrm{dpl}$, Bukit Rindingan $1500 \mathrm{~m} \mathrm{dpl}$, gunung Tanggamus $2100 \mathrm{~m} \mathrm{dpl}$, gunung Betung $1240 \mathrm{~m}$ dpl. Hulu sungai tersebut semula 
mengalir ke timur / timurlaut sampai ke tenggara dan bermuara di laut Jawa Bentang alam yang dilintasi oleh sungai-sungai di DAS Sekampung membentuk bentang alam perbukitan, dataran, dataran rendah yang diselingi oleh daerah endapan dan rawa-rawa. Ada 11 (sebelas) sungai yang cukup besar yang bermuara di sungai Sekampung. Aliran sungai Sekampung terbendung oleh basalt Sukadana, sehingga alirannya beralih ke tenggara. Akibat lain yang ditimbulkan adalah terbentuknya cekungan, daerah banjir dan rawa yang luas. Di antara rawa yang luas tersebut adalah rawa Sragi Ke-8 situs megalitik yang diteliti ini terletak pada daratan yang tinggi dan kering, baik yang terletak pada bentukan lahan punggungan bukit, rawa ataupun dataran rendah. Dari 8 situs tersebut, 5 diantaranya terletak pada satuan formasi bentang alam DAS Sekampung yang disebut dengan 'Sebagou' atau dalam 'Land Use Mapping' disebut dengan 'SBG'. Bentang alam ini terdiri dari tanggul-tanggul sungai yang sangat luas yang terbentuk oleh endapan-endapan sungai muda dan endapan vulkanik. Kemiringan mencapai $0-2 \%$. Relief permukaan tanahnya cenderung datar. Mineral yang terkandung di sini mempunyai hutir yang halus dan didominasi oleh aluvium. Kandungan jenis tanahnya pada bagian atas terdiri dari 'Tropufluen' dengan tekstur halus; pada bagian tengah adalah 'Tropoquepst', dengan tekstur cukup halus; dan pada bagian bawah adalah 'Fluvaueints' dengan tekstur halus. Situs-situs dengan bentang alam 'SBG' diwakili oleh situs Bentengsari, Gedig, Parigi, Meris, dan Cicilik, yang mengelompok pada bagian hilir. Situs lainnya seperti Gelombang mempunyai bentang alam yang disebut 'Barong Tongkok' ('BTK') Unik fisik 'BTK' terdiri dari dataran tinggi ataupun daerah perbukitan yang terbentuk oleh endapan lahar basah dengan kemiringan lereng $66 \%$. Oleh sebab itu situs ini hanya mempunyai parit saja tidak mempunyai gundukan tanah seperti situs serupa lainnya. Daerah ini oleh penduduk setempat dinamakan gelombang karena memang permukaan tanahnya bergelombang sebagai akibat dari proses penggalian parit di dataran yang memang morfologisnya miring. Situs ini juga mempunya penampang lintang dengan lembah yang dalam dan agak curam. Kandungan mineral yang dominan disini adalah basalt, andesit, terra berbutir halus hingga kasar. Dengan kandungan mineral seperti ini tidak heran apabila pada sisi bagian dalam situs tersebut banyak ditemukan batuan andesit yang kelihatan bekas dipangkas sebagian yang disusun berjajar. Selain itu pula ditemukan dolmen dengan batu penyangganya. Adapula bata datar ('slapstone') yang sebagian dipangkas. Adapun jenis tanah yang dikandungnya adalah 'Distropets' pada bagian atas dengan tekstur halus. Pada bagian tengah adalah 'Tropudalts' dengan tekstur kasar, dan pada bagian bawah adalah 'Tropudults' dengan tekstur halus.

Situs Pejambon mempunyai bentang alam yang disebut dengan 'Sungai Alur' atau 'SAR' Bentang alam ini merupakan dataran yang terbentuk oleh endapan tufa schingga membentuk bukit-bukit kecil dengan kemiringan 16-25\%. Penampang lintang terbentuk oleh adanya endapan Mineral yang dikandung oleh bentang alam ini adalah didominasi oleh batu lumpur, batu lanau, batu pasir, tufit, dan tefra berbutir halus Kenis tanah situs ini adalah pada bagian atas terdiri dari 'Paleudults' dengan tekstur agak halus sampai 
halus; bagian tengah adalah 'Flaplorthox' dengan tekstur agak halus sampai halus. Bagian bawah terdiri dari jenis 'Dystropepts' dengan tekstur cukup halus sampai agak halus

Situs Pugung Raharjo mempunyai bentang alam yang disbeut 'Sungai Medang' ('SMD') Unit fisik bentang alam ini adalah berbukit atau bergelombang. Datarannya merupakan dataran vulkanik basah yang berombak sampai bergelombang yang terbentuk oleh batuan beku basah. Situs ini mempunyai ketinggian $\pm 50 \mathrm{~m}$ dpl dengan kemiringan 9$15 \%$. Penampang lintangnya merupakan dataran bergelombang. Mineral yang dikandungnya didominasi pada lapisan atas oleh batuan basalt dan andesit, sehingga memungkinkan tersedianya bahan dasar bagi pembuatan bangunan punden. Pada sisi bagian dalam dan luar situs terdapat \pm 14 punden, namun yang bisa teridentifiksi dengan jelas baru 8 punden saja. Batuan lain yang tersebar sebagai tinggalan arkeologis adalah batu fondasi, batu bergores, batu lumpang, batu berlubang, 'batu mayat', dsb.

\section{Penutup}

Dari penelitian atas bangunan-bangunan tanah tersebut dapat diketahui bahwa pemukiman masa megalitik di DAS Sekampung adalah pemukiman yang dibangun dengan membuat parit serta gundukan tanah. Pemukiman ini dapat dibuat dengan membangun gundukan tanah dan parit ataupun parit saja bentuk permukaan tanah pemukiman ini berbeda-beda. Ada yang mengikuti pola bentukan alam yang sudah tersedia dan ada pula yang tidak. Ada yang letaknya dekat dengan sungai utama ada pula yang letaknya jauh dari sungai utama. Situs-situs yang terletak pada sungai utama antara lain situs Pejambon, Gedig, Parigi dan Meris; sedangkan situs-situs yang terletak pada anak sungai Sekampung adalah situs Gelombang, Pugung Raharjo, Cicilik, dan Bentengsari. Bentuk situs yang tidak mengikuti bentang alam dan bentuknya beraturan adalah situs Parigi.

Secara umum ke-8 situs tersebut secara geografis terletak pada suatu dataran yang tinggi dan kering, baik yang terletak pada bentukan lahan punggungan bukit, rawa maupun dataran rendah. Situs-situs ini terletak dekat dengan sumber air, yang bisa berupa mata air, kandungan air tanah yang besar ataupun sungai Sekampung itu sendiri. Mencermati keletakan situs yang dekat dengan sungai bukan hal yang aneh apabila transportasi yang digunakan keluar masuk situs dan antar situs adalah dengan transportsi air, misalnya saja perahu. Adanya beberapa temuan yang sama di beberapa situs yang dihubungkan dengan bentuk sungai yang bercabang-cabang ('pola dendritic') juga bisa mengilhami adanya kegiatan perdagangan antar situs dengan 'model dendritic' pula. Di mana juga diperlukan perantara yang merupakan penghubung antara daerah pesisir dan pedalaman. Adapun barang yang diperdagangkan ataupun dipertukarkan sebagai komoditi antara lain tembikar, manik-manik, porselen dan benda logam. 
Berkenaan dengan uraian tersebut di atas maka dapat diketahui kegiatan yang dilakukan suatu komunitas dalam suatu situs berdasarkan temuan artefaknya. Pada situs-situs ini maka kegiatan yang dilakukan adalah bermukim, berkebun, bertani, berdagang dan pertukangan atau penganjun.

\section{KEPUSTAKAAN}

Adkins, Lesley dan Roy A Adkinds. 1994. Archaeological Illustration, Cambridge, University Press

Bintoro, H.R.1995 "Keterkaitan manusia. Ruang dan Kebudayaan", Berkala Arkeologi Manusia dalam Ruang: Studi Kawasan dalam Arkeologi Th XV, edisi khusus, Balai Arkeologi Yogyakarta.

Butzer, Karl W. 1964. Environment and Archaeology: An Introduction to Pleistocene Geography, Aldine Pub Company.

Crumley, Carole L dan Marquandt, William H. 1990 "landscape: Unifying Concept in Regional Analysis: Interpretating Spac" GIS and Archaeology: Taylor and Francis.

Finzi, Cludio Vita. 1978. Archaeological Sites in the Setting, Thames and Hudson

Haryadi, nfn. (1995). Kemungkinan Penerapan Konsep Sistem Seting Dalam Penemukenalan Penataan Ruang Kawasan. Berkala Arkeologi, 15(3), 5-9. https:// doi.org/10.30883/jba.v15i3.664

Mundardjito. 1994 Pertimbangan Ekologi dalam Penempatan Situs Masa Hindu-Budha di daerah Yogyakarta: Kajian Arkeologi Ruang Skala Makro, Disertasi FS UI Jakarta.

Parson, J.R. I 972 "Archaeological Settlement Pattern" In Annual Review of Anthropology 1:77-150.

Schiffer, Michael B. 1989 Archaeology Methods and Theory vol 7 the University of Arizona press

Subroto, P. (1995). Pola-Pola Zonal Situs-Situs Arkeologi. Berkala Arkeologi, 15(3), 133-138. https://doi.org/10.30883/jba.v15i3.685

Triwurjani, Rr dan Fadhlan S.I. TT. Laporan Penelitian Arkeologi di DAS Sekampung Bidang Arkeometri, Pusat Penelitian Arkeologi Jakarta.

Triwurjani Rr. 1996-1997. Laporan Alokasi Situs-istus Sepanjang DAS Sekampung, Bidang Arkeometri, Pusat Penelitian Arkeologi Nasional Jakarta. 


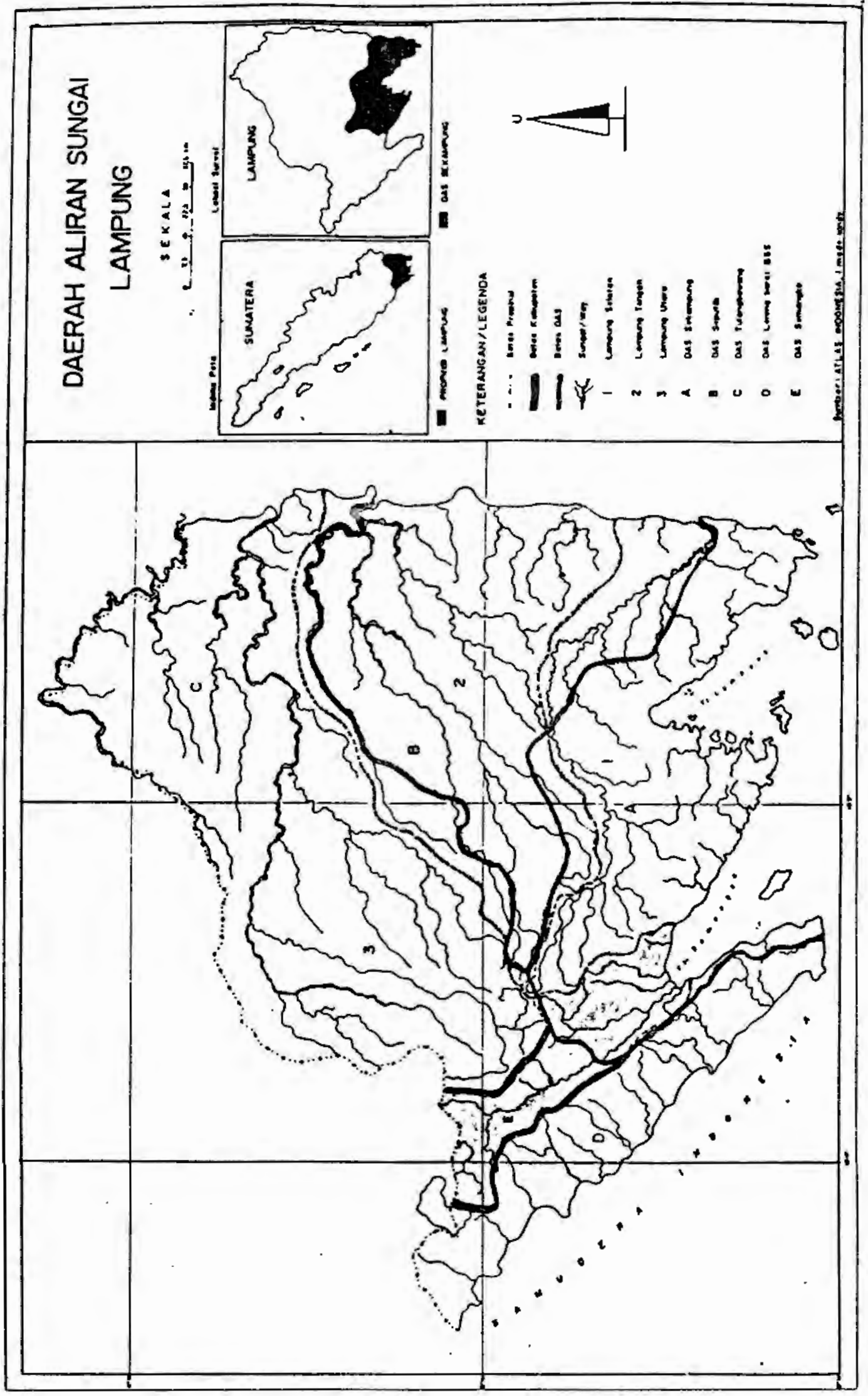




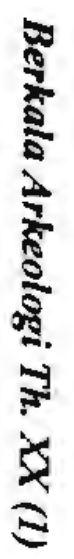

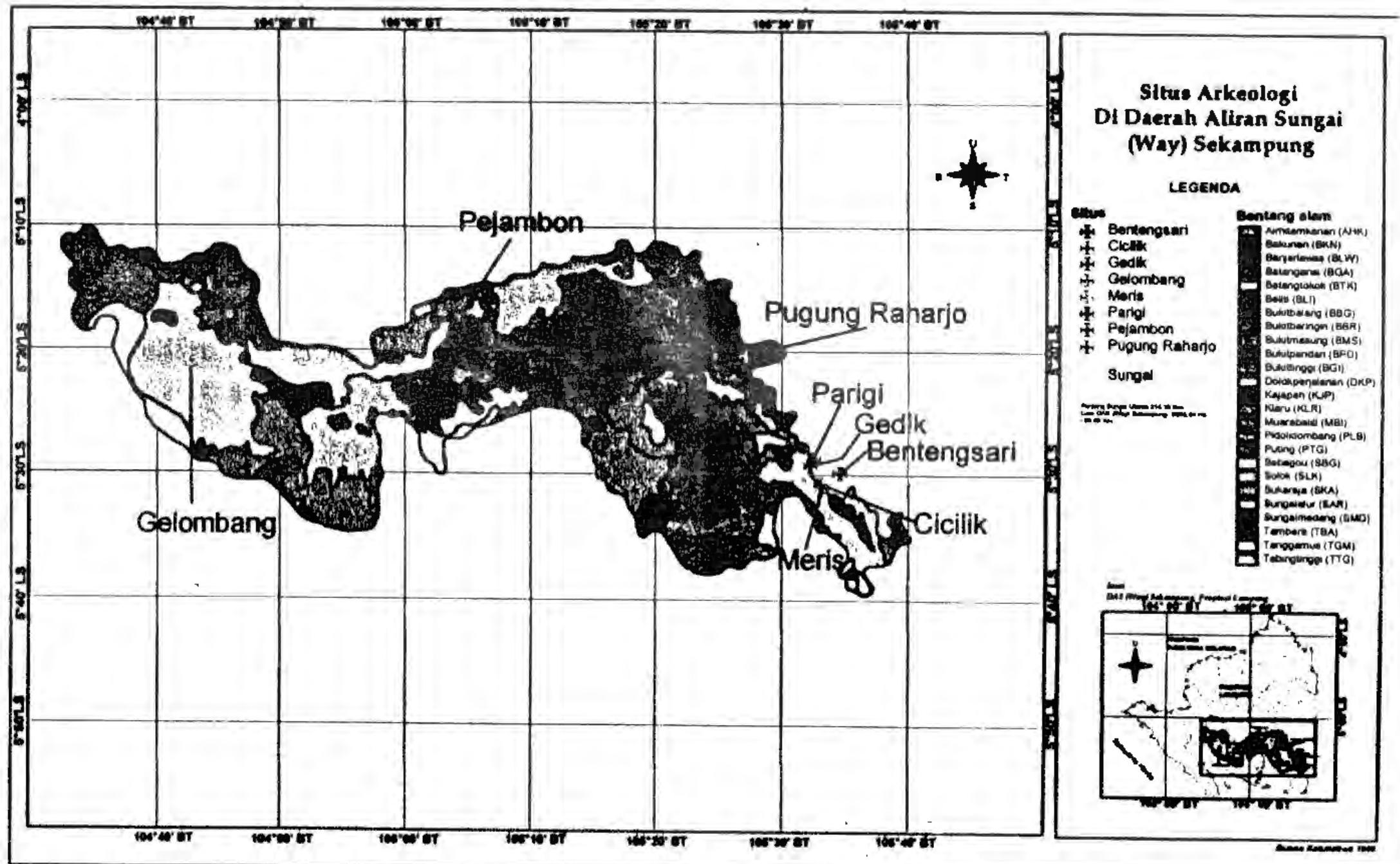




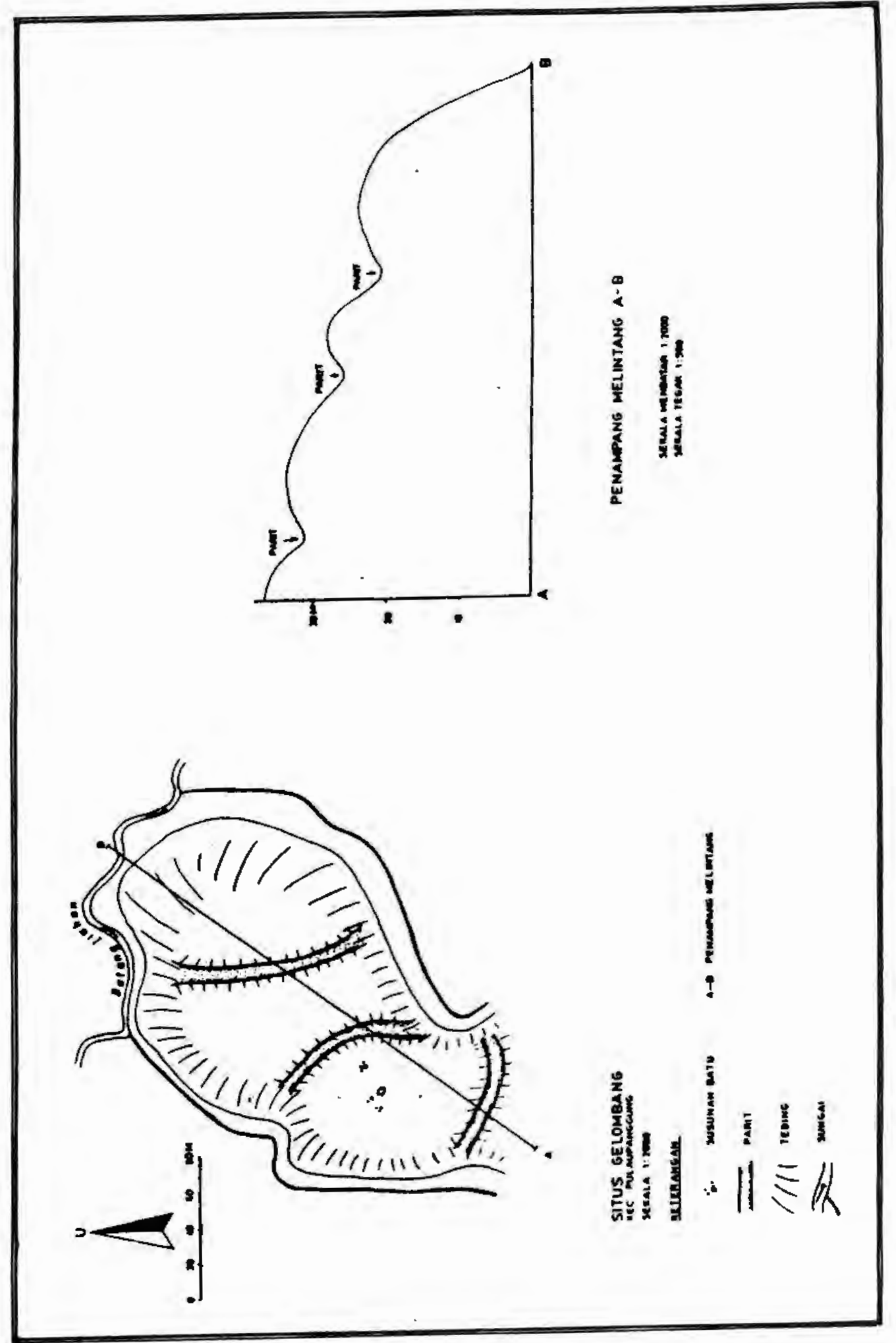

Berkala Arkeologi Th. XX (l) 


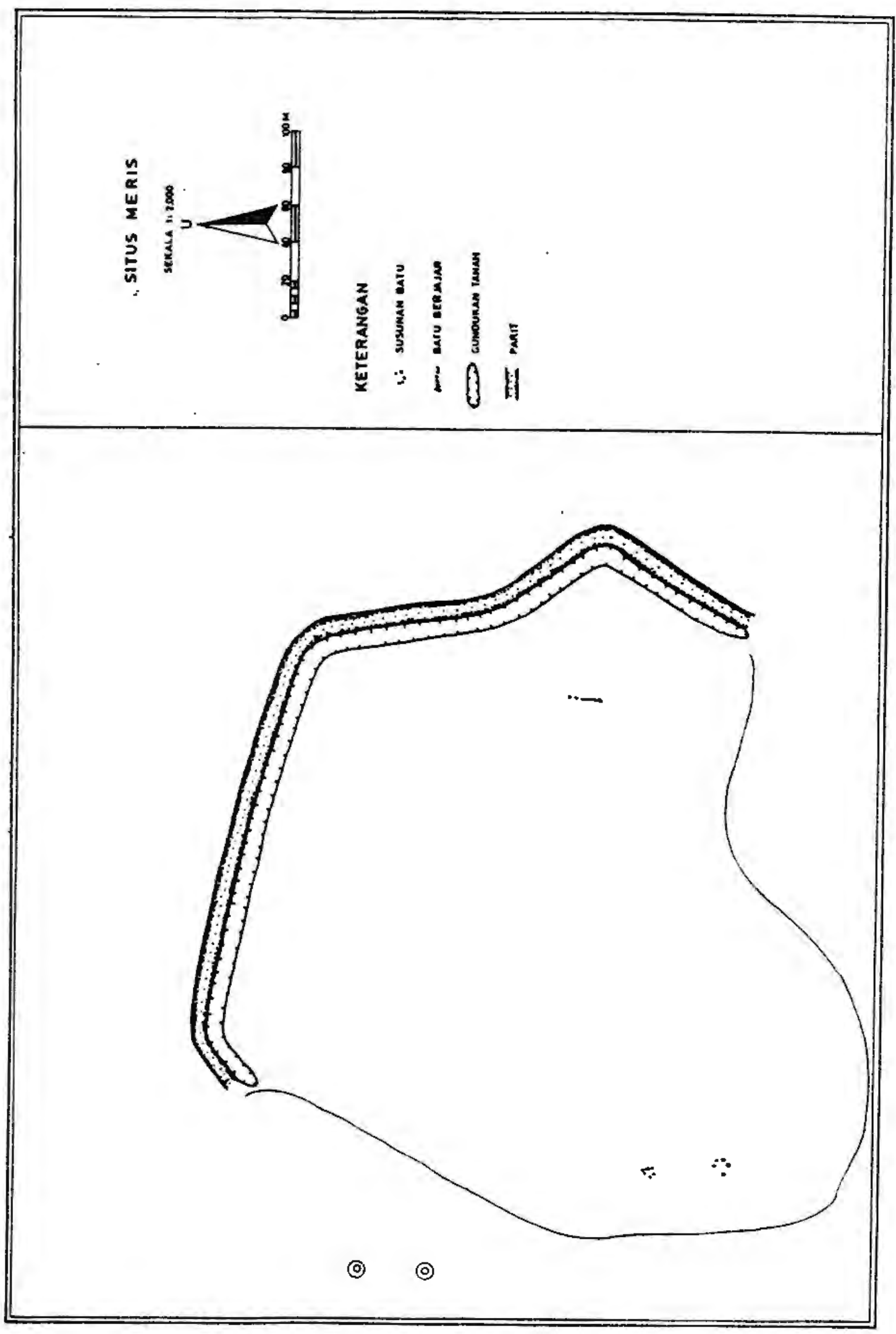




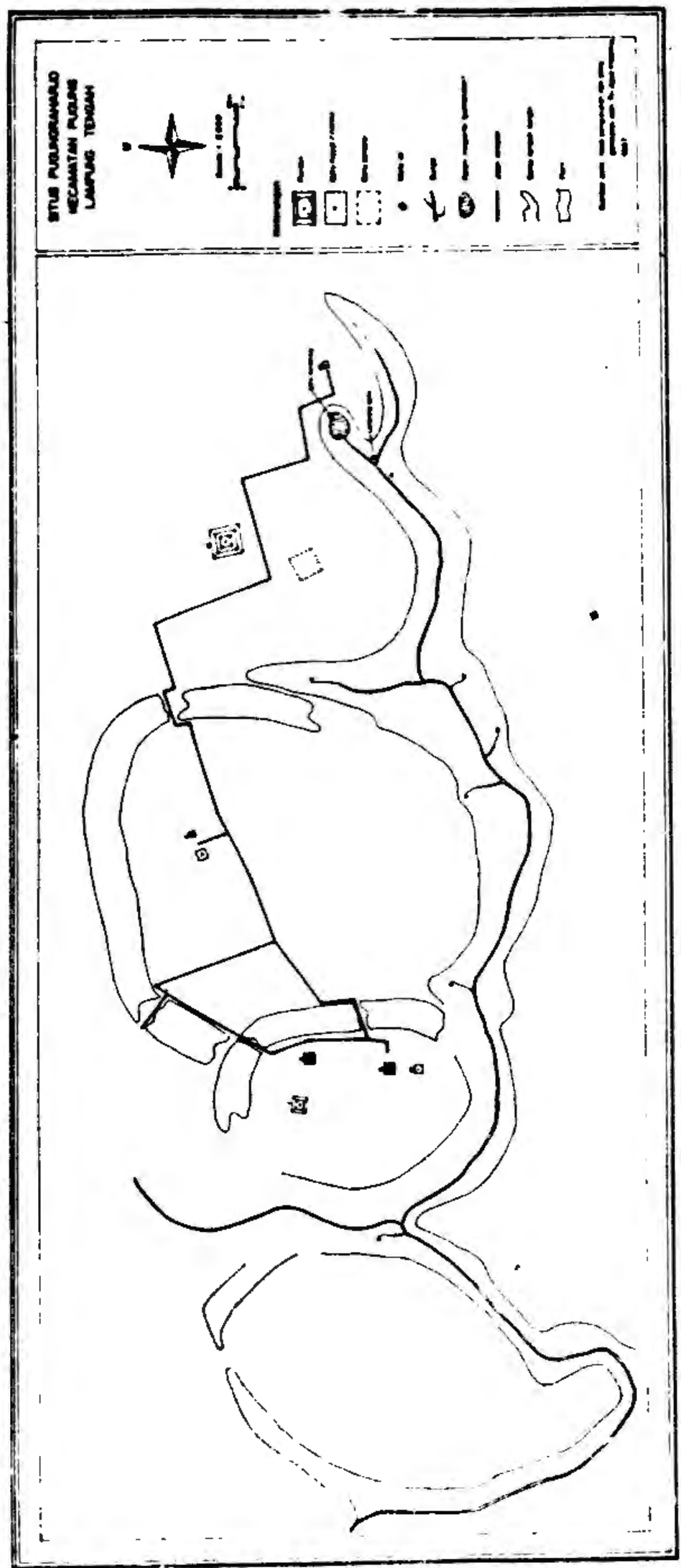

